\title{
THE INFLUENCE OF GEAR MICROPUMP BODY ASYMMETRY ON STRESS DISTRIBUTION
}

\author{
Wacław Kollek, Prof. \\ Piotr Osiński \\ Urszula Warzyńska \\ Wrocław University of Science and Technology, Poland
}

\begin{abstract}
The paper presents the results of numerical calculations of stress distributions in the gear micropump body for applications in hydraulic systems, especially in the marine sector. The scope of the study was to determine the most favorable position of bushings and pumping unit in the gear pump body in terms of stress and displacement distribution in the pump housing. Fourteen cases of gear pump bushings and pumping unit locations were analyzed: starting from the symmetrical position relative to the central axis of the pump, up to a position shifted by $2.6 \mathrm{~mm}$ towards the suction channel of the pump. The analysis of the obtained calculation results has shown that the most favorable conditions for pump operation are met when the bushings are shifted by $2.2 \mathrm{~mm}$ towards the suction channel. In this case the maximal stress was equal to $109 \mathrm{MPa}$, while the highest displacement was about $15 \mu \mathrm{m}$. Strength and stiffness criteria in the modernized pump body were satisfied.
\end{abstract}

Keywords: gear micropump, microhydraulics, finite element method

\section{INTRODUCTION}

Gear pumps are the most common group of positive displacement pumps used in hydrostatic drive systems as power generators, as well as in lubrication systems in various onshore and offshore applications. The gear pump design presented in the paper is frequently used in ship machines and devices, rescue equipment, and oil rigs. In particular, the asymmetric-body micropumps can be used in hydraulic units of davit lifeboats, ramps of horizontal loading systems, as well as in control units of anchor and mooring systems. The main advantages of these pumps include: simple and compact design, high durability, and relatively low price. Furthermore, they are characterized by high reliability and resistance to working medium impurities, high efficiency, and small size, compared to other pumps. These features are of special importance in marine engineering. Currently, a wide variety of gear pump and engine designs provide improvement of hydraulic and acoustic properties, the description of which can be found in the literature $[2,7,15$,
$17,19,20,21,22]$. The development of modern gear units is associated with the following trends: increasing operating pressure $[6,18]$, improving total efficiency $[4,10,15,18,23]$, reducing pressure pulsations $[3,18,25]$, minimizing weight $[15]$ and noise $[11,14,16]$, and reducing dynamic loads [7, 12, $13,19]$. Introducing certain modifications to the pump design and searching for the optimal design is possible through the use of modern computer aided design (CAD) techniques and numerical methods $[5,7,8,9,14,24]$. In recent years, a strong trend can be observed towards reducing the size and weight of hydraulic elements and systems, which stimulates intensive development of a new area of hydraulics bearing the name of microhydraulics. Reducing the size of the gear pump may be associated with the resultant reduction in production costs, however it is necessary to adequately determine the strength of the construction during the operation of the system. Therefore, the below reported numerical calculations have been performed to allow initial optimization of geometric dimensions of the micropump body. The main object of the analysis was the influence of bushing and pumping unit 
locations in the micropump on the stress and displacement distribution in the micropump body.

\section{GEOMETRIC MODEL AND MATERIAL PROPERTIES}

The geometric model of the micropump body was prepared on the basis of technical documentation of the gear micropump prototype PZ0 manufactured during the implementation of the developmental grant No. 030032 04/2008 (Figure 1). The prototype unit consists of three-parts, which are: flange, pump body, and cover. All the components are bolted together. The elements mounted in the pump housing include: two gear units, i.e. drive gear and idler gear-pumping unit, bushings, suction and pressure ports for connection to the drive system, and sealing.
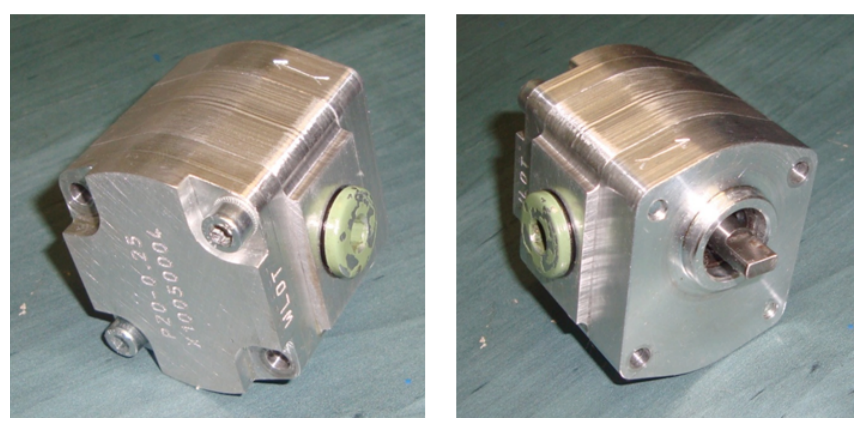

Figure 1. Photography of the pump PZ0 prototype

The dimensions of the pump body prototype were modified based on the results of the previously performed numerical analyses [8]. The overall output dimensions of the body were reduced by $25 \%$, in comparison to the initial dimensions, while maintaining the shape and fixed dimensions - the size of the suction and discharge channels, and the size of the bushings. The modified gear micropump body was found to satisfy the strength and stiffness criteria, and therefore this micropump was used as a base model for further modifications. The geometric model of the pump body was initially prepared in Autodesk Inventor software and then subsequently modified in Ansys Multiphysics software. During successive program loop iterations, the location of bushings in the pump casing was shifted toward the suction channel, thus introducing an asymmetry in the pump body. The housing with asymmetrical position of gears was previously described in [1]. The calculations were performed for fourteen cases of bushing positions, with their shift ranging from $0 \mathrm{~mm}$ to $2.6 \mathrm{~mm}$ relative to the symmetry axis of the pump body. Figure 2 shows extreme positions of bushings and the pumping unit: a - basic position "0", b maximum position " 2.6 ".
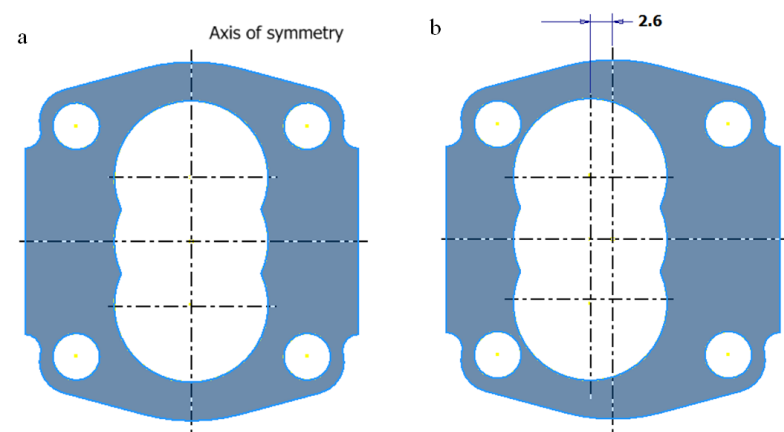

Figure 2. Gear micropump body: a - basic model, b- maximal shift of bushings

The prototype of the gear micropump body is made of aluminum alloy PA6 (EN-AW-2017A). This alloy is characterized by good strength properties and high tensile and fatigue strength. Mechanical and physical properties of the alloy, taken from Polish Standard PN-84/H-93669, are presented in Table 1 . These parameters were used for numerical calculation and further analysis of the results.

Table 1. Properties of aluminum alloy PA6 (EN-AW-2017A)

\begin{tabular}{|l|c|}
\hline \multicolumn{1}{|c|}{ Property [unit] } & Value \\
\hline Tensile strength $\mathrm{R}_{\mathrm{m}}[\mathrm{MPa}]$ & 390 \\
\hline Yield strength $\mathrm{R}_{0.2}[\mathrm{MPa}]$ & 250 \\
\hline Density $\rho\left[\mathrm{g} / \mathrm{cm}^{3}\right]$ & 2.79 \\
\hline Tensile modulus $\mathrm{E}[\mathrm{MPa}]$ & 72500 \\
\hline Poisson's ratio $v[-]$ & 0.33 \\
\hline
\end{tabular}

\section{COMPUTATIONAL PROCEDURE}

For the purpose of numerical stress calculations in the gear micropump body with different bushing and pumping unit locations, the calculation procedure in APDL language was prepared and implemented in Ansys Multiphysics environment. The procedure includes a few steps. At the beginning the core geometry of the micropump body is loaded as a parasolid file, then the offset of bushings in the suction channel direction is to be introduced - this value is given in millimeters and ranges from 0 to $2.6 \mathrm{~mm}$. The maximum offset of the bushings is limited by the holes for screws bolting together particular pump parts - flange, pump body, and back cover. After entering the desired value the program modifies the basic geometry of the gear pump body by performing appropriate Boolean operations on solids. Once the geometric model is prepared, the discrete mesh is generated. Material properties of the model which are needed for calculations are implemented based on the values listed in Table 1 . Then the model is fixed and properly loaded. The calculation results are saved in a .db file. During the analysis, the entire calculation cycle starting from entering the bushing location offset was repeated fourteen times for different bushing positions. The calculation algorithm is schematically shown in Figure 3. 


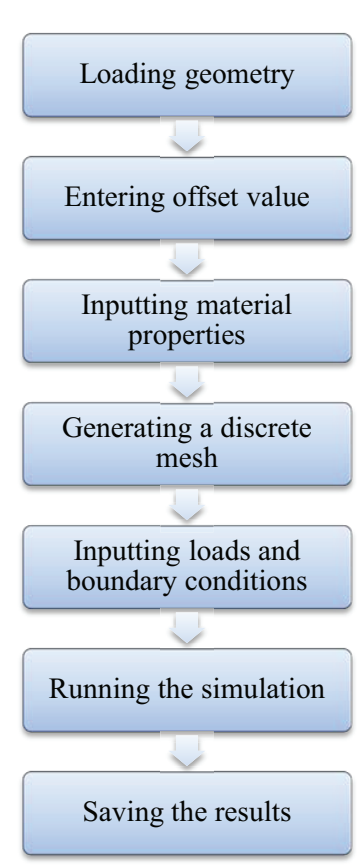

Figure 3. Algorithm of micropump body stress calculations

\section{DISCRETE MODEL, LOADS AND BOUNDARY CONDITIONS}

The geometric model of the micropump body was divided into higher-order tetrahedral finite elements (solid187). Each element includes ten nodes - at the vertices and at each edge of the tetrahedron. The element is adapted to model irregular meshes, especially for complex geometries from CAD/ CAM systems. In each node of the element, three degrees of freedom, representing possible movements in three axes: $x$, $\mathrm{y}$ and $\mathrm{z}$, are defined. The applied mesh elements ensure high accuracy of calculations in the complex model geometry [26]. The discrete model of the pump body is shown in Figure 6.

The previous research $[6,7]$ has shown that the pressure along the gear circumference has different character depending on the pump design (Figure 4). In the case of radial clearance compensation, the pressure and suction spaces are tightly separated at the discharge side. The sealing effect within a small area is associated with sharp pressure increase over a short distance in the small chamber. This is advantageous for the pump body strength; however, the abrupt pressure jump is always accompanied by increased sound emission into the environment. For this reason, in modern pump designs a trend towards sealing along the circumference at the suction side is observed. Moreover, this type of sealing is a natural consequence of the resultant force originating from fluid pressure acting on the circumference. The main disadvantages of this solution are slightly lower hydraulic-mechanical efficiency and greater stress in the pump body, nevertheless slow pressure increase decreases the level of the emitted noise by as much as $10 \mathrm{~dB}$.
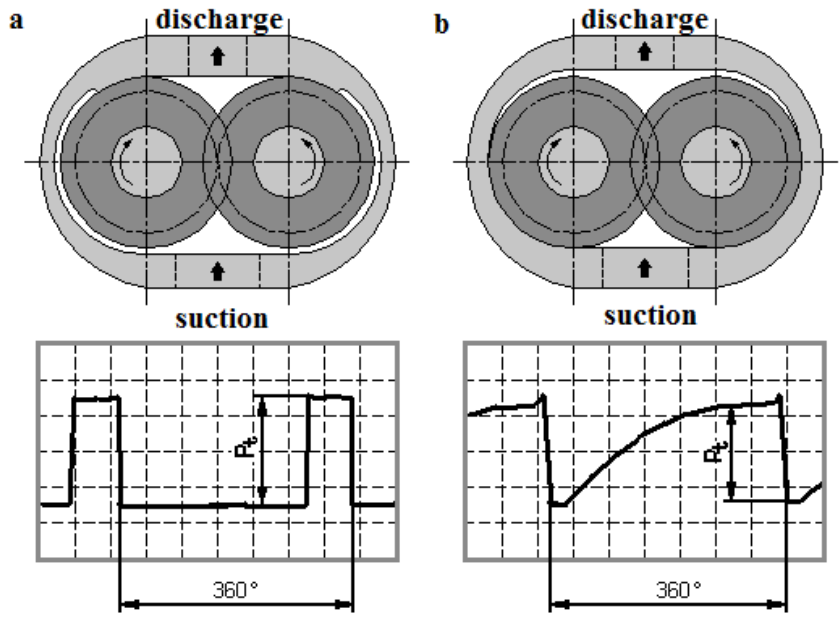

Figure 4. Schematic of circumferential sealing of gears and graph of circumferential pressure distribution measured in the tooth space: $a$-discharge side, $b$ - suction side

The analyzed pump design belongs to the group in which sealing is applied at the suction side. Thus, the theoretical time-history $\mathrm{p}(\mathrm{t})$ of pressure changes in the gear pump during one full gear rotation $(2 \pi)$ is similar to that shown in Figure 5. Here, four specific zones may be distinguished:

- suction zone

$\varphi_{1} \quad p(t)=p_{s}$

- zone of linear pressure increase

$\varphi_{2} \quad p_{s}<p(t)<p_{t}$

- zone of constant discharge pressure

$\varphi_{3} \quad p(t)=p_{t}$

- zone of pressure change in the trapped volume $\varphi_{4} \quad p(t)=p_{z}=p_{t}+\Delta p_{z}$

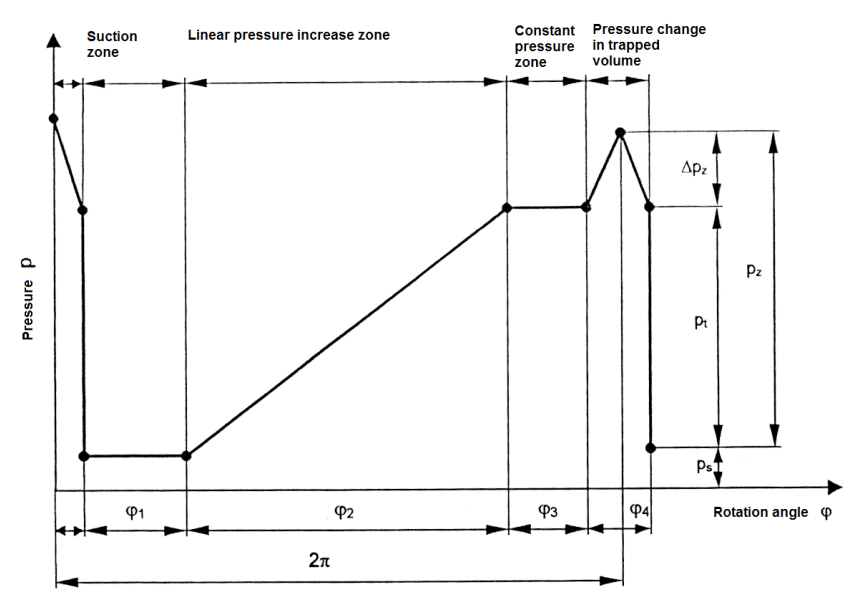

Figure 5. Theoretical pressure time-history in gear pump during full gear rotation

Properly designed units are characterized by marginal surplus pressure $\Delta \mathrm{p}_{\mathrm{z}}$ in the $\phi 4$ zone. In this case $\mathrm{p}_{\mathrm{z}}=\mathrm{p}_{\mathrm{t}}$ and the model of pump can be simplified to three pressure zones: suction zone $\mathrm{p}_{\mathrm{s}}$, linear pressure increase zone, and constant discharge pressure zone $\mathrm{p}_{\mathrm{t}}$. 
Therefore, the existence of two pressure zones were assumed in the model, which were: the zone of linear pressure growth, and the zone of discharge pressure. Additionally, the zone of bearing pressure on the pump body was modeled (Figure 6). The values of pressure increase angles were determined from circumferential pressure measurements. The zone of pressure increase covers the angle of $73^{\circ}$ in which the pressure rises from $0 \mathrm{MPa}$ to $28 \mathrm{MPa}$ (marked red in Figure 6). The suction pressure is negligibly small, compared to the discharged pressure, and therefore was not included in the model. The pump body was loaded symmetrically on the drive and idler gear side. In the model, the reaction force on the bearings was considered (green zone in Figure 6). The model was pinned in four holes for screws connecting the pump elements.

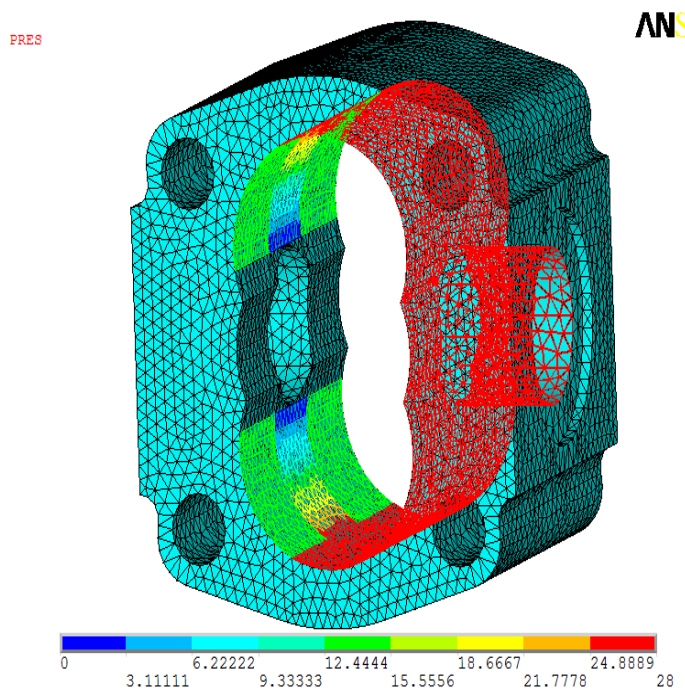

Figure 6. Schematic of discrete gear pump body model and load distribution

\section{RESULTS OF FEM ANALYSIS}

Numerical simulations were performed to determine optimal positions of the bushings and the pumping unit in the pump body. The bushing locations were moved from $0 \mathrm{~mm}$ to $2.6 \mathrm{~mm}$, with the step of $0.2 \mathrm{~mm}$, toward the suction channel of the pump. The linear static strength calculations were performed using the finite element method. The stress distributions in the pump housing model were evaluated against the Huber-Mises hypothesis and the displacement vector sum. In each simulation case, the discrete model, loads and boundary conditions were introduced in the same manner.

The performed numerical calculations have shown that the most preferred location of bushings and pumping unit in the gear pump housing is when they are shifted by $2.2 \mathrm{~mm}$ from the pump symmetry axis position. In this case, the values of stress and displacement in the pump body are the smallest. In the asymmetrical pump body with $2.2 \mathrm{~mm}$ bushing offset the maximum stress decreased by nearly $18 \%$, compared to the symmetric pump body configuration. The results of numerical simulations for the initial and optimized model are shown in Figures 7 and 8 as contour plots.

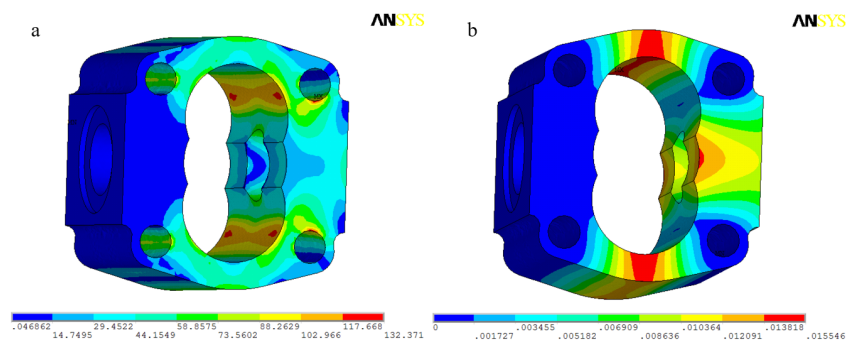

Figure 7. Distribution of stress(a) and displacement (b) in micropump bodyinitial position of bushings
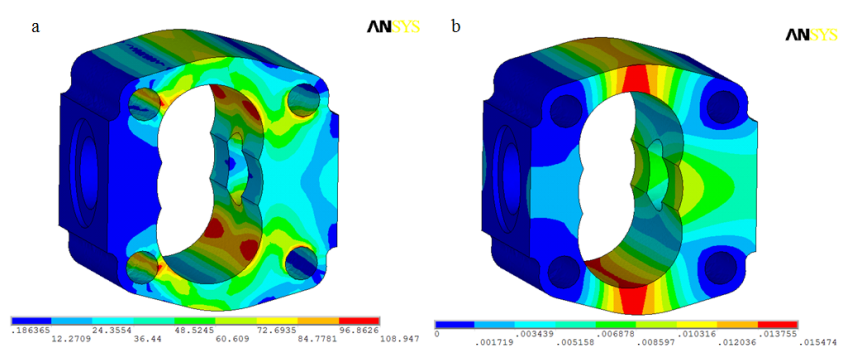

Figure 8. Distribution of stress(a) and displacement (b) in micropump bodybushings location „2.2”

Figure 8a shows the stress distribution in the gear pump body with bushings shifted by $2.2 \mathrm{~mm}$ toward the suction channel. The highest stress values can be observed in the contact area of the pump body and the bearing, and along the edges of holes for fastening screws on the discharge side of the housing. The maximum stress in the pump body equals $109 \mathrm{MPa}$ and is significantly smaller than the yield strength $(250 \mathrm{MPa})$ and the tensile strength $(390 \mathrm{MPa})$ of aluminum alloy PA6 (Table 1). In the remaining parts of the body, the stress values are much lower than the maximum value. On the suction channel side, the stress values are close to zero. The safety factor for the modified micropump body is approximately equal to 3.58 .

$$
n=\frac{\sigma_{n}}{\sigma}=\frac{390}{109} \approx 3.58
$$

The displacement distribution in the micropump body with bushing location offset equal to $2.2 \mathrm{~mm}$ from the axis of symmetry toward the suction channel is shown in Figure $8 \mathrm{~b}$. The largest displacements can be observed in the upper and lower part of the pump housing, above bushings. This results from the pressure increase during pump operation, which at these points reaches the maximum value of $28 \mathrm{MPa}$. The maximum displacement occurring in the pump body equals 0.015 and does not exceed the clearance limit specified in the papers $[6,16]$. The optimized design of the pump housing fulfills the strength and stiffness criteria.

The results of the subsequent numerical simulations for all analyzed geometries are shown in the graph in Figure 10. 
This comparison of the results bases on the maximum stress and displacement values. The nodes at which these values occur are shown in Figure 9.

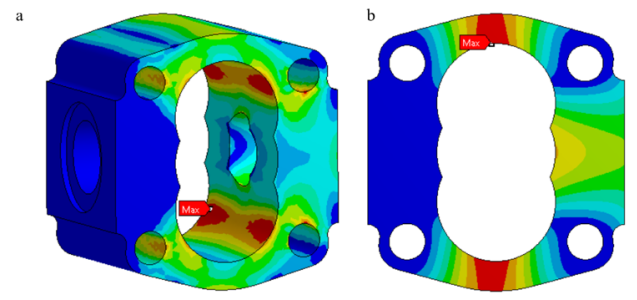

Figure 9. Location of measuring points of the maximum stress and displacement in the pump body

When analyzing the stress and displacement curves as functions of pumping unit offset from the axis of symmetry, the maximal stress and displacement values are observed for the basic symmetrical position (offset equal to 0 ). The maximal stress is equal to $132 \mathrm{MPa}$, while the largest displacement equals $0.016 \mathrm{~mm}$. In each subsequent simulation, the stress and displacement values decrease until the offset of $2.2 \mathrm{~mm}$ is reached. In this case the maximum stress value is about $109 \mathrm{MPa}$, and the maximum displacement value is about $0.015 \mathrm{~mm}$. In the two remaining cases, in which the bushing offsets toward the suction channel was set equal to $2.4 \mathrm{~mm}$ and $2.6 \mathrm{~mm}$, respectively, significant increase of maximal stress value is observed. This is caused by too extensive shift which leads to unacceptably small material layer between the bolt holes and the bushings.

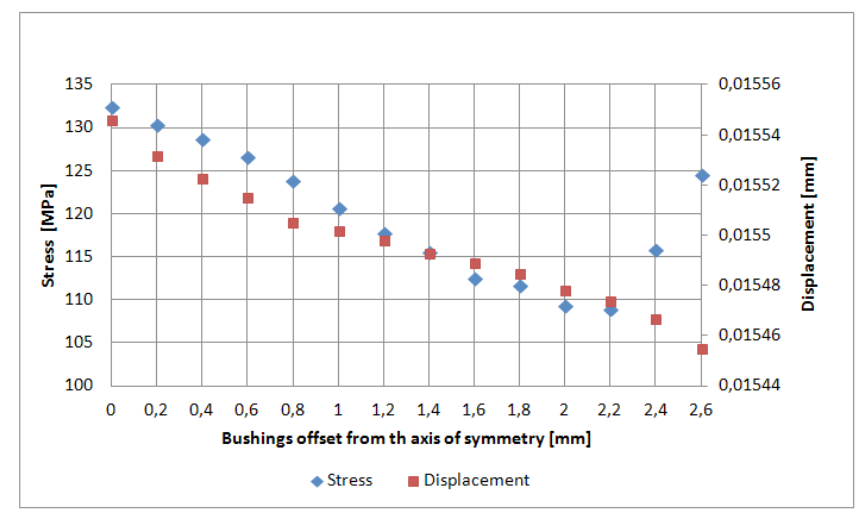

Figure 10. Stress and displacement as functions of bushing offset

\section{CONCLUSIONS}

In the paper, the influence of bushing and pumping unit positions on the stress and displacement distribution in the gear micropump body is examined. The static linear analysis based on the results of numerical simulation calculations performed using the finite element method. It has been observed that the most preferred location of bushings in the pump housing is the position with $2.2 \mathrm{~mm}$ offset from the axis of symmetry toward the suction channel. In this case the maximum stress in the pump body reaches 109MPa and does not exceed the yield and tensile stress limits for aluminum alloy PA6. In the gear pump body model, the safety factor of 3.58 was assumed. The recorded maximum stress in the modernized pump housing with bushing location shifted by $2.2 \mathrm{~mm}$ from the axis of symmetry is lower by $18 \%$ than that in the symmetrical pump. The largest displacements appear in the zone of constant discharge pressure along the gear circumference. The maximum displacements do not exceed $16 \mu \mathrm{m}$, and should not have a negative impact on leak tightness of the pump during its operation. Consequently, the space increase between the tooth tip and the pump body should not lead to the decrease of volumetric efficiency. The results presented in the paper are the introduction to the experimental research and determine the direction of future work. As part of further research, their verification will be provided by experimental stress measurements in pump bodies during the operation of prototype units.

\section{REFERENCES}

1. Biernacki K., Stryczek S., PL Patent Application No. 123143, 06.06.2014

2. Casoli P., Vacca A., Berta G.L., Optimization of relevant design parameters of external gear pumps, 7th International Symposium on Fluid Power, Toyama 2008.

3. Casoli P., Vacca A., Franzoni G., A numerical model for the simulation of external gear pumps, 6th JFPS International Symposium on Fluid Power, Tsukuba, 2005.

4. Dhar S., Vacca A., A novel CFD - Axial motion coupled model for the axial balance of lateral bushings in external gear machines, Simulation Modelling Practice and Theory, 2012, 67, pp 60-76.

5. Ghionea I., Ghionea A., Constantin G., $C A D$ - CAE methodology applied to analysis of a gear pump, Proceedings in Manufacturing Systems, 2013, vol.8, issue 1.

6. Kollek W., Pompy zębate - Konstrukcja i eksploatacja, Ossolineum, Wrocław 1996.

7. Kollek W., Osiński P., Modelling and design of gear pumps, Oficyna Wydawnicza Politechniki Wrocławskiej, Wrocław 2009.

8. Kollek W., Radziwanowska U., Energetic efficiency of gear micropumps, Archives of Civil and Mechanical Engineering, 2015, Vol. 15, Issue 1, pp 109-115.

9. Li H., Yang Ch., Zhou P., The finite element analysis and optimizations of shells of internal gear pumps based on Ansys, Fluid Power and Mechatronics ,2011, pp 185-190. 
10. Lipski J., Napęd i Sterowanie Hydrauliczne, Wydawnictwa Komunikacji i Łączności 1981.

11. Lączkowski R., Wibroakustyka Maszyn i Urządzeń, Wydawnictwo Naukowo-Techniczne, 1983.

12. Mucchi E., Dalpiaz G., Experimental Validation of a Model for the Dynamic Analysis of Gear Pumps, ASME 2013 International Design Engineering Technical Conferences and Computers and Information in Engineering Conference, Volume 5: 25th International Conference on Design Theory and Methodology; ASME 2013 Power Transmission and Gearing Conference, Portland, Oregon, USA, August 4-7, 2013.

13. Mucchi E., Dalpiaz G., Fernandez del Rincon A., Elastodynamic analysis of a gear pump. Part I: Pressure distribution and gear eccentricity, Mechanical Systems and Signal Processing, 2010, 24, p. 2160-2179.

14. Mucchi E., Rivola A., Dalpiaz G., Modelling dynamic behaviour and noise generation in gear pumps: Procedure and validation, Applied Acoustics, 2014, 77, pp 99-111.

15. Osiński P., Deptuła A., Partyka M. A., Discrete optimization of a gear pump after tooth root undercutting by means of multi-valued logic trees, Archives of Civil and Mechanical Engineering, 2013, vol. 13, No. 4, pp 422-431, http://dx.doi.org/10.1016/j.acme.2013.05.001

16. Osiński P., Kollek W., Assessment of energetistic measuring techniques and their application to diagnosis of acoustic condition of hydraulic machinery and equipment, Archives of Civil and Mechanical Engineering, 2013, vol. 13, nr 3, pp 313-321, http://dx.doi.org/10.1016/j. acme.2013.03.001

17. Osiński P., Modelling and design of gear pumps with modified tooth profile, LAP Lambert Academic Publishing. Saarbrucken 2014

18. Osiński P., Wysokociśnieniowe i niskopulsacyjne pompy zębate o zazębieniu zewnętrznym, Oficyna Wydawnicza Politechniki Wrocławskiej, Wrocław 2013.

19. Ragunathan C., Manoharan C., Dynamic analysis of hydrodynamic gear pump performance using design of experiment stand operational parameters, IOSR Journal of Mechanical and Civil Engineering, 2012, vol. 1, issue 6, pp 17-23.

20. Singal R.K., Singal M., Singal R., Hydraulic Machines. Fluid Machinery, I.K. International Publishing House, New Delhi, 2009.
21. Sliwiński P., Flow of liquid in flat gaps of the satellite motor working mechanism, Polish Maritime Research 2(82) 2014 Vol 21, pp 50-57.

22. Śliwiński P., The basics of design and experimental tests of the commutation unit of a hydraulic satellite motor, Archives of Civil and Mechanical Engineering, 2016, vol. 16, issue 4, pp 634-644, doi:10.1016/j.acme.2016.04.003.

23. Stryczek S., Napęd Hydrostatyczny, Wydawnictwo Naukowo-Techniczne, Warszawa 2005.

24. Vacca A., Guidetti M., Modelling and experimental validation of external spur gear machines for fluid power applications, Simulation Modelling Practice and Theory, 2011, 19, pp 2007-2031.

25. Wang S., Sakurai H., Kasarekar A., The optimal design in external gear pumps and motors, ASME Transactions on Mechatronics, 2011, vol. 16, no. 5.

26. http://www.kxcad.net/ansys/ANSYS/ansyshelp/Hlp E SOLID187.html

\section{CONTACT WITH THE AUTHOR}

\author{
Wacław Kollek \\ e-mail: waclaw.kollek@pwr.edu.pl \\ Politechnika Wrocławska \\ Łukasiewicza 7/9 \\ 50-371 Wrocław \\ Polska \\ Piotr Osiński \\ e-mail:piotr.osinski@pwr.edu.pl \\ Politechnika Wrocławska \\ Łukasiewicza 7/9 \\ 50-371 Wrocław \\ Polska \\ Urszula Warzyńska \\ e-mail:urszula.radziwanowska@pwr.edu.pl \\ Politechnika Wrocławska \\ Łukasiewicza 7/9 \\ 50-371 Wrocław \\ Polska
}

